\title{
UPAYA PENINGKATAN PELAYANAN SUPERVISI UNTUK MENINGKATKAN KINERJA GURU DI SEKOLAH
}

\author{
Oleh: Liarni \\ Liarniani01@gmail.com \\ Universitas Negeri Padang
}

\begin{abstract}
Abstrak
Pendidikan di Indonesia sangat ditentukan oleh pelaksanaan supervise yang dilakukan pada setiap lembaga pendidikan.peningkatan layanan supervise sangat berpengaruh pada proses pelaksanaan supervise.dimana kualitas pembelajaran yang sangat jauh dari kata bermutu,kualitas pendidikan yang masih rendah.seharusnya memicu pelaksanaan supervise ditingkatkan.keruntutan pelaksanaan yang harus sistematis dalam melaksanakan,untuk mendapatkan proses supervise dapat berjalan sesuai yang di inginkan.supervisi sangat membantu dalam meningkatkan kinerja guru.yang selalu dilakukan pengawasan atau supervisi sangat berbeda kinerja dengan gutu yang tidak dilakukan supervise, dimana seseorang akan meningkat kinerjanya apabila ada yang mengawasinya.maka teori dan teknik supervise sangat perlu diterapkan oleh supervisor dalam melakukan pengawasan.
\end{abstract}

Kata Kunci:supervisi,peningkatan,kinerja guru,sekolah,pelayanan supervisi untuk meningkatkan kinerja guru

\section{PENDAHULUAN}

Pentingnya pendidikan untuk membangun aspek lain seperti aspek ekonomi ,aspek social ,aspek pemerintah.dimana semua itu sabfat bergantung pada pendidikan .oleh sebab itu perbaikan penddikan sangat diperlukan sehingga aspek lainpun dapat ditingkatkan dengan adanya sdm yang berkiualitas.untuk meningkatkan pendidikan yang bermutu dapat dilakukan 
dengan pelayanan supervisi yang ada.sebenarnya pelayanan supervisi dilakukan untuk meningkatkan kualitas pembelajaran si setiap sekolah-sekolah.

Secara umum supervisi ini ada terbagi kedalam bentuk yang pertama supervisi akademik,diamana supervisi ini lebih menekankan pada pengawasan dalam pembelajaran.dimana supervisi dilakukan dalam dalam rangka menjamin mutu pendidikan agar mutu pendidikan dapat meningkat.Membangun manusia Indonesia dimana mempersiapkan bangsa Indonesia menjadi warga negara yang bertanggung jawab serta mampu mewujudkan masyarakat yang adil dan makmur berdasarkan Pancasila dan patuh pada norma ynag berlaku. Hal ini sesuai dengan amanat yang tercantum dalam pembukaan Undang-undang Dasar 1945 yang penjabarannya tertuang dalam batang tubuhnya Bab XII Pasal 31. (1) Tiap warga negara berhak mendapat pengajaran. (3) PemerintahMembangun manusia Indonesia berarti mempersiapkan bangsa Indonesia untuk menjadi warga negara yang bertanggung jawab dan mampu mewujudkan masyarakat yang adil dan makmur berdasarkan Pancasila. Hal ini sesuai dengan amanat yang tercantum dalam pembukaan Undang-undang Dasar 1945 yang penjabarannya tertuang dalam batang tubuhnya Bab XII Pasal 31. (1) Tiap warga negara berhak mendapat pengajaran. (3) Pemerintah

Suatu Proses mengusahakan dan menyelenggarakan sistem pendidikan nasional, yang untuk meningkatkan pengembangan perilakau keimanan dan ketakwaan serta akhlak mulia dalam rangka untuk mencerdaskan kehidupan bangsa, yang diatur dengan undang-undang. karena itu pentingnya pendidikan dimana pendidikan merupakan sesuatu system yang terdiri dari beberapa komponen.,yang selalu berkembang serta berubah sesuai dengan penigkatan kebutuhan zaman, oleh sebab itu adanya fungsi pengatutran dari pendidikan itu sendiri sebagai pedomanpelaksanaan kebijakan pendidikan. Di Indonesia fungsi pendidikan secara nasional dirumuskan dalam UU nomor 20 Tahuin 2003.

Di dalamnya dijelaskan bahwa fungsi pendidikan nasional adalah mengembangkan kemampuan dan membentuk watak serta peradaban bangsa yang bermartabat dalam rangka mencerdaskan kehidupan bangsa, bertujuan untuk berkembangnya potensi peserta didik agar menjadi manusia yang beriman dan bertakwa kepada Tuhan Yang Maha Esa, berakhlak mulia, sehat, berilmu, cakap, kreatif, mandiri, dan menjadi warga negara yang demokratis serta bertanggung jawab. Di dunia internasional, mutu pendidikan Indonesia berada di peringkat ke-64 
dari 120 negeri di semua dunia berdasarkan laporan tahunan UNESCO Education For All Global Monitoring Report 2012. Sedangkan berdasarkan Indeks Perkembangan Pendidikan atau Education Development Index (EDI), Indonesia berada kepada peringkat ke-69 dari 127 negeri terhadap 2011. Melihat data di atas mengindikasikan bahwa pendidikan di Indonesia harus masih ditingkatkan lagi kualitasnya. Dalam praktik pendidikan, yang mempunyai peran penting sebagai dasar bagi pendidikan di tingkat selanjutnya adalah pendidikan dasar. Pendidikan dasar sebagai jenjang pendidikan awal mempunyai peranan yang mendasar dalam upaya mengembangkan potensi peserta didik. Pendidikan dasar secara lebih khusus sekolah dasar merupakan tempat awal pembentukan karakter bagi peserta didik. Selain memiliki potensi yang tinggi, usia sekolah dasar memiliki resiko yang tinggi juga. Jika anakusia sekolah dasar mengalami salah penanganan maka dampaknya akan terus berlanjut sampai dewasa.

Dalam rangka mencapai suatu pendidikan yang berkualitas terutama di tingkat pendidikan dasar maka perlu upaya mengoptimalkan kualitas sumber daya pendidikan. Salah satu sumber daya tersebut adalah tenaga yang bergerak sebagai tenaga kependidikan kependidikan. Baik itu meliputi komponen teratas di tingkat kementrian sampai di tingkat terdepan yaitu sekolah. Guru adalah salah satu komponen sumber daya pendidikan yang ada di sekolah guru memiliki peran yang sangat besar dalam pendidikan, di pundaknya dibebani suatu tanggung jawab atas mutu pendidikan. Guru merupakan suatu profesi, yang berarti suatu jabatan yang memerlukan keahlian khusus sebagai guru dan tidak dapat dilakukan oleh sembarang orang di luar bidang pendidikan,Hal ini sejalan dengan UU nomor 20 tahun 2003 tentang Sistem Pendidikan Nasional yang menyatakan bahwa pendidik merupaka tenaga profesional . Kariman dalam buku yang ditulis oleh Hamzah juga mengutarakan profesionalisme seorang guru merupakan suatu keharusan Guru harus mengembangkan dirinya dengan ilmu pengetahuan dan keterampilan-keterampilan yang dibutuhkan dalam pembelajaran. guru adalah komponen sumber daya manusia yang harus dibina dan dikembangkan terus-menerus.

\section{Pandangan pemberian layaanan supervisi pendidikan}

Pada saat ini pendidikan sangat berkembang seiring dengan perkembangan zaman yang selalu berubah.dimana awalnya supervisi dilakukan dengan suatu pendekatan,supervisor datang langsung ke sekolah, saat tiba di suatu sekolah ,supervisor tersebut mengamati,apa saja yang menjadi kekurangan dalam proses pembelajaran. Seiring dengan berkembangnya suatu 
manajemen bahwa kualitas pendidikan sangat ditentukan oleh professional guru dan kualitas gguru dalam mengajar.tapi terkadng banyak pandangan yang menilai proses supervisi.dimana pelaksanaan supervisi menjadi pemantau guru dalam pembelajaran,oleh sebab itu ada pandanga negative terhadap pelaksanaannya .terkadng tidak semua lembaga merasa butuh dipantau atau dilakukan pengawasan.guru merasa terganggu dengan datangnya supervisor ke sekolah ,sebenarnya yang mana dating untuk meningkatkan kinerja guru bukan hanya untuk mencari kesalahan saja.seharusnya lembaga sekolah menerima dengan baik dan senang hati karena pross supervisi sangat membantu meningkatkan kinerja guru dan memperbaiki apa saja yang menjadi kekurangan.

Menurut Ahmad Sabandi dalam jurnalnya yang Berjudul supervisi Pendidikan Untuk Pengembangan Profesionalitas Guru Berkelanjutan, dimanaPengembangan profesi guru dilaksanakan melalui berbagai program pendididkan, pra-jabatan, maupun maupun program dalam jabatan. Namun, tidak semua guru yang dididik dalam berbagai program tersebut menunjukkan kinerja yang mumpuni. Dalam berita yang diakses dalam website kemdibud mamaparkan bahwa hasil uji kompetensi yang dilakukan selama tiga tahun terakhir menunjukkan bahwa mutu atau kualitas guru di Tanah Air saat ini masih rendah. Hal ini diungkapkan Kepala Badan Pengembangan Sumber Daya Manusia Pendidikan Kebudayaan (BPSDMPK) dan Peningkatan Mutu Pendidikan (PMP), Kementerian Pendidikan dan Kebudayaan (Kemdikbud), Syahwal Gultom, saat menjadi pembicara pada Seminar Mutu Pendidikan Nasional yang digelar Lembaga Penjaminan Mutu Pendidikan (LPMP) Maluku bekerja sama dengan Kemdikbud. Ia juga mengakui masih banyak guru terutama di daerahdaerah yang tidak lulus uji kompetensi dan sertifikasi sebagai akibat rendahnya kualitas merekaPemeberian layanan supervisi kecilnya pengaruh kegiatan supervisi yang dilaksanakan terhadap kinerja guru. sehingga mengindikasikan adanya faktor lain yang lebih berpengaruh terhadap kinerja guru di luar kegiatan supervisi. Faktor tersebut dapat berupa tingkat kepangkatan guru, besar gaji, tingkat pendidikan guru, usia dan sebagainya

peningkatan kinerja semua komponen pendidikan akan menjadi baik serta peran dan tanggung jawab guru akan meningkat apabila dilaksakannya kontrol dan penilaian terhadap semua komponen-komponen yang terkait dalam dunia pendidikan. kontrol yang dimaksud adalah Supervisi pendidikan. tujuan supervisi pendidikan adalah untuk membantu guru mengembangkan kemampuannya, mencapai tujuan pengajaran yang dicanangkan bagi 
muridmuridnya. Maka dapat diambil kesimpulan sementara bahwa untuk menjaga kualitas kinerja guru maka perlu adanya quality qontrol dalam bentuk supervisi pendidikan terhadap guru-guru di sekolah.

Pemberian supervisi haruslah sesui dengan prosedur yang ada sehingga tidak ada penyimpangan maupun pelanggarana yang dilakukan oleh orang yang disupervisi maupun yang melakukan supervisi tersebut.pelayanan supervisi harus diberikan dengan maksimal sehingga keinginan untuk menigkatkan kinerja guru dapat berhasil.pemberian pelayanan ini dapat berupa melakukan sesuai dengan sistematis yang benar dan meningkatkan kode etik dalam melakukannya,dengan etika sopan santun yang diberikan oleh yang melakukan supervisi maka orang yang disupervisi merasa dihargai dan merasa nyaman untuk dilakukan supervisi.

\section{Cara peningkatan pelayanan supervisi}

Setiap orang yang ingin dilakukan supervisi pasti ingin dilakukan supervisi yang baik,baik dari segi ingin mendapatkan informasi dan pemberian pelayanan yang baik.seorang supervisi dengan kedatangannya tidak mengganggu kinerja guru.maka seorang supervisor harus tau strategi yang ia gunakan sehingga kedatangannya dapat disambut hangat oleh guru dan guru yang disupervisi mau untuk dilakukan supervisi.

Adapun cara ampuh yang bisa dilakukan seorang supervisor adalah sebagai berikut

1. Melakukan supervisi sesuai tujuan supervis tersebut,tidak puunya maksud lain dalam melakukan supervisi

2. Sebaiknya melakukan supervisi dimana tidak megganggu jalan kinerja seorang guru tersebut.

3. Melakukan supervisi dengan etika yang baik dan tidak menyinggung perasaan guru yang akan disupervisi

4. Tidak menyinggung masalah pribadi orang yang akan dilakukan supervisi, tujuan supervisi memang mutlak untuk melakukan supervisi untuk meningkatkan kinerja saja

Setiap supervisor harus menumbuhkan rasa kenyaman dalam pelaksanaan supervisi tersebut.seorang guru akan mau melakukan supervisi apabila dalam proses supervisi yang ia alami dilakukan dengan pelayanan yang baik .dalam melakukan tugasnya sebagai pengajar yang 
susah payah mengabdi pada masyarakat untuk mendidik anak bangsa untuk meningkatkan kualitas indonesia yang lebih maju.

Dengan adanya peningkatan pelayanan supervisi ini diharapkan semua guru yang akan dilakukan supervisi dapat meningkatkan kinerjanya menjadi guru yang profesional.sehingga setelah dilakukan supervisi guru dapat melakukan inovasi terhadap proses pembelajaran yang yang lebih menarik,kondusif,dan peserta didik dapat menangkap pelajaran yang diberikan.maka untuk meningkatkan inovasi yang akan dilakukan guru maka pelayanan dalam melakukan supervisi harus dioptimalkan dengan pemberian layanan yang terbaik .

\section{Kendala-kendala dalam pemberian layanan supervisi}

Melakukan supervisi tidaklah semudah yang dibayangkan ,banyak rintangan untuk melakukannnya.baik dari segi instrumen yang digunakan ataupun dari segi pelayanan yang diberikan yang terkadang salah paham,serta penerimaan lembaga yang akan dilakukan supervisi.adapun kendala yang akan muncul dalam melakukan supervisi adalah sebagai berikut:

1. instrumen yang digunakan kurang lengkap,sehingga proses dan tata urutan dalam mensupervisi menjadi rancu

2. Terjadinya miskomunikasi antara orang yang melakukan supervisi dengan orang disupervisi,sehingga proses pelaksanaan supervisi tersebut.

3. Pemberian pelayanan yang kurang sopan dalam melakukan supervisi oleh supervisor,sehingga guru merasa terganggu dalam dalam proses supervisi tersebut.

4. Adanya instansi yang kurang menerima dalam proses pelaksanaan supervisi tersebut,dimana pihak guru tidak benar-benar dalm melakukannnya

5. Adanya pembocoran pemberitahuan akan dilakukan supervisi sehingga hasil yang diberikan tidak real lagi,dan adanya manipulasi dalam kualitas yang tidak seharusnya

\section{Upaya untuk peningkatan pelayanan supervisi}

Dalam melakukan supervisi pasti adanya rintangan dan tantangan yang ditemukan dalam pelaksanaan,sehingga untuk mengurangi hal itu terjadi maka perlu upaya untuk mencegah terjadinta penyimpangan tersebut.adapun upaya yang dapat dilakukan dalam meningkatkan 
pemberian pelayanan supervisi yaitu dengan mengadakan instrumen yang lengkap sehingga dalam pelaksanaan tidak terjadi kesalahan dalam mendata maupun melakukan supervisi.seorang supervisor yang harus memiliki tatakrama yang baik sehingga penerimaan supervisor tidak menciptakan citra negatif.sekolah harus siap untuk dilakukan supervisi.

Dengan adanya peningkatan pelayanan supervisi ini diharapkan meningkatnya kinerja guru dalam proses pembelajaran.sehingga tujuan dari supervisi dapat tercapai dimana prestasi dari peserta didik dapat meningkat.dan menimbulkan efek positif terhadap lembaga tersebut.pemberian layanan yang baik pasti sangat berdampak pada kegiatan yang akan diadakan.seorang supervisor harus mamahami situasi dan kondisi untuk pelaksanaan supervisi tersebut.

\section{Pelaksanaan supervisi di indonesia}

Perkembangan pelaksanaan supervisi di indonesia berkembang seiringnya perkembangan pengetahuan dan teknologi sosial, interaksi masyarakat.pelaksanaan supervisi misih didominasi oleh supervisor,dimana seorang supervisor berkolaborasi dengan guru untuk melaksanakan supervisi dan bertanggung jawab dalam peningkatan kualitas pendidikan di indonesia,serta menumbuhkan semangat belajar dan mengajar yaang kompetetif

\section{Pendekatan pelaksanaan supervisi}

Dalam melakukan supervisi maka sangat diperlukan yang namanya pendekatan baik itu dari perencanaan sampai proses mengolah.beberapa pendekatan supervisi yang umum digunakan yaitu dengan pendekatan klinis ,penembangan,serta diferensial.diamana masing-masing pendekatan memiliki kelebihan dan kekurangan.tidak ada fokus satu pendekatan saja

\section{a. Pendekatan klinis}

Pendekatan ini merujuk pada interaksi tatap muka antara guru dan supervisi yang menekankan pada pemecahan masalah reflektif dimana targer secara masing-masing kelas.dan terfokus pada guru sebagai agen perubahan

b. Pendekatan pengembangan 
Pendekatan ini memperlakukan guru sebagai individu sebagai yang berada pada tahap pertumbuhan dan perkembangan.pendekatan ini didasarkan pada asumsi bahwa guru memiliki beragam pengalaman,kemampuan dan tingkat pengembangan karir yang berbeda

\section{c. Pendekatan differensial}

Dimana pendekatan menyediakan pilihan pendekatan yang cocok digunakan, pendekatan ini merujuk pada bahwa tidak ada satu pendekatan untuk semua supervisi

\section{KESIMPULAN DAN SARAN}

Simpulan dari analisi Berdasarkan data penelitian dan pembahasan maka dapat disimpulkan bahwa tidak tertdapat pengaruh positif dan signifikan pelaksanaan supervisi pendidikan oleh kepala sekolah terhadap kinerja guru di sekolah dasar. Dengan demikian hipotesis yang menyatakan "terdapat pengaruh yang positif dan signifikan pelaksanaan supervisi pendidikan oleh kepala sekolah terhadap kinerja

kepada kepala sekolah dalam kegiatan penilaian kinerja guru diharapkan dilaksanakan dengan sebenar-benarnya sesuai kondisi nyata di lingkup kerjanya tanpa rasa ewuh pekewuh sebagaimana temuan peneliti bahwa hasil penilaian kinerja guru cenderung menilai dengan skor baik, sehingga kurang menunjukkan kinerja guru yang sebenarnya. Bagi Guru seharusnya lebih mamahami atasannya maupun rekan kerjanya baik secara personal maupun secara professional. Secara personal maksudnya, mbangun hubungan yang baik antar individu dengan kepala sekolah maupun rekan kerjanya sebagaimana kompetensi sosial seorang guru. secara profesional maksudnya guru diharapkan dapat memiliki hubungan atasan dengan bawahan maupun sesame guru secara profesional sebagaimana ketentuan yang berlaku..

Sedangkan bagi penelitian selanjutnya diharapkan dengan saran-saran diatas apabila dilaksanakan dengan baik maka akan mempermudah penelitian tindak lanjut dalam penelitian ini, serta diharapkan dapat lebih memberikan hasil penelitian yang lebih optimal. Dan hendaknya, penelitian selanjutnya lebih memperhatikan faktor-faktor di luar kegiatan supervisi apabila inigin mengetahui hal-hal yang mempengaruhi kinerja guru. 


\section{DAFTAR PUSTAKA.}

Sabandi, A. (2013). Supervisi Pendidikan Untuk Pengembangan Profesionalitas Guru Berkelanjutan. PEDAGOGI,Jurnal Ilmiah Ilmu Pendidikan, XIII(2), 1-9. 